an affection which, throughout his life, he fully reciprocated. Félix Moureu died only last year, at the age of seventy-eight. $\mathrm{He}$ was a pharmacist of distinction in Biarritz, ten years Mayor of the town; he did much to develop its attractions. Charles Moureu's early training was in his brother's pharmacy at Biarritz. In Paris, he quickly passed through the courses in pharmacy and those at the Sorbonne. He qualified as pharmacist, in the first class, in 1891. After serving, during several years, as chief assistant, he was admitted to the Faculty of Pharmacy in 1899 and became professor of pharmaceutical chemistry in 1907. Ten years later he succeeded Jüngfleisch, Berthelot's successor in the chair of chemistry at the Collége de France. $\mathrm{He}$ also became Director of the Verdun Agricultural Research Station, founded by Berthelot. He was elected into the Academy of Medicine in 1907 and into the Academy of Sciences in 1911. During more than thirty years he has been a prolific worker.

Moureu began by studying various vegetable essences, eugenol, etc. He also worked on alkaloids, determining the constitution of sparteine. Following the Berthelot tradition, he devoted himself to synthetic studies in the acetylene series. His most noteworthy discovery is that of the red hydrocarbon, rubrene, which is remarkable on account of the way in which it simulates the behaviour of hæmoglobin towards oxygen, absorbing the gas with avidity, when irradiated, forming a colourless peroxide from which the oxygen may be removed by exposure in a vacuum. If heated, at temperatures below $140^{\circ}$, this gives off oxygen alone, to within 80 per cent of the theoretical amount. Even at ordinary temperatures, if exposed to light but not in the dark, the peroxide dissociates reversibly, the dissociation pressure at $16^{\circ}$ being of the order of $0.5 \mathrm{~cm}$. of mercury. Light is emitted during the deoxidation. If the hydrocarbon be subjected to oxygen in admixture with either benzaldehyde or propionic aldehyde only the rubrene absorbs the gas; its oxidation is retarded by quinol and other anti-oxidants; it is not oxidised at all in the presence of carbonic oxide. Moureu has suggested, in view of the behaviour of rubrene towards oxygen, that in oxyhæmoglobin the oxygen may well be in organic connexion with the molecule, not through the iron.

From 1906 onwards, Moureu devoted himself to the study of the rare gases present in French mineral waters, oil springs, etc., even extending his researches in this field to Madagascar, where he made a careful survey of the chemical resources of the island. For this last service he was promoted to the rank of Grand Officer of the Legion of Honour. A summary of his work on the rare gases was presented to our Chemical Society, of which he was an honorary member, in a lecture which he delivered on June 14, 1923. Fifty-seven springs in all were studied. The results are very remarkable. The amount of helium present varied greatly, reaching 5.92 per cent in the gas collected at Maizieres, Côte d'Or. The other gases, krypton, argon, neon and xenon, however, were present in practically the same proportion, whatever the source. In 1913 he initiated an Institute of Hydrology and Climatology for the study of mineral waters and problems of climate in France and its colonies.

Being familiar with acrolein from his early studies, during the War Moureu sought to utilise this aldehyde as a tear excitant. The difficulty was to preserve it unchanged, as it soon set to a solid. Having traced the polymerisation to the action of acid formed by atmospheric oxidation, he set to work to discover means of preventing the change. He soon found that a great variety of substances could be used as anti-oxidants: phenols, aldehydes, amines, even potassium iodide. From 1919 onwards, Dufraisse and he, assisted by various young workers, systematically explored the field thus opened up, with the result that we are now in possession of a mass of exact data of extreme value. The full importance of the work, in its bearing upon vital phenomena, is yet to be realised. It is already clear that, more often than not, when two oxidisable substances are together subjected to attack by oxygen gas, oxidation is apparently inhibited because both are simultaneously oxidised to oxides which interact reversibly. Obviously, if the living organism were not in some way protected against excessive oxidation, through the heat developed, the action would necessarily tend to take place at an increasing rate: there is little doubt that, through what may be termed the Moureu effect, a control is exercised preventing excessive action. Maybe the office of some advitants is of this order.

Moureu's work in general is characterised by a breadth and philosophical exactitude which renders it of special importance and value. In him we lose a true chemist of the old school-a man who worshipped at the shrine of severe laboratory practice, a cult to-day by no means overpopular even in France. Fortunately, the name survives in his son, already a young chemist of distinction.

Henry E. Armstrong.

\section{Mr. H. C. Robinson.}

Mr. Herbert Christopher Robinson, who was born in Liverpool on Nov. 4, 1874, died on May 30 last, after an illness which had lasted for nearly a year. Mr. Robinson belonged to one of the leading Liverpool families, whilst one of his uncles, Mr. William Fothergill Robinson, had been Vice-Chancellor of the Duchy of Lancaster.

Robinson was educated at Marlborough College, and on leaving school went to the Royal School of Mines, for which he had obtained a scholarship. In 1894, constant ill-health compelled him to give up his studies, and he then commenced his career as a zoologist at Davos, where he resided for a couple of years. Here his health considerably im. proved, and in 1896 he went to Queensland, where he made a large collection of birds in Cooktown and its vicinity, but was obliged to return home owing to chronic dysentery. On his return to England he was appointed an assistant in the Liver. pool Museum, where between 1897 and 1900 he

No. 3119 , VoL. 124] 
assisted Dr. H. O. Forbes to publish catalogues of the bird collections in that Museum. In 1901 he accompanied Dr. N. Annandale, who was then Director of the Indian Zoological Survey, to the Malay Peninsula, on an expedition attached to the Skeat Expedition which had been organised by the Royal Society of Edinburgh and by the University of Liverpool. The results of this expedition appeared in several volumes between. 1903 and 1907, that on birds being written by Mr. Ogilvy Grant in 1905-but the work, which was entitled " Fasciculi Malayenses", was unfortunately never completed.

In $1903 \mathrm{Mr}$. Robinson was appointed curator of the Federated Malay States Museums, and shortly afterwards, on the resignation of the Director, $\mathrm{Mr}$. Wray, he was promoted to that appointment, which he held until his resignation in 1926. From this time forward Mr. Robinson-latterly often in conjunction with $\mathrm{Mr}$. Boden Kloss-wrote from time to time many articles on the various branches of zoology, though principally on the Vertebrata. In addition to this, Mr. Robinson organised and directed both the Federated Malay States Bureau of Fisheries and also the Meteorological Service. For the last two years of his service Mr. Robinson was in charge of a section of the Malayan Pavilion at the Wembley Exhibition. Throughout his directorship of the Federated Malay States Museums, Mr. Robinson wrote principally in the Journal of those Museums, the Journal of the Asiatic Society, and, to a less extent, in the Ibis.

$\mathrm{Mr}$. Robinson was not only a scientific ornithologist with a wide knowledge of the literature of birds, but was also himself a keen and indefatigable field naturalist with an intimate knowledge of the birds in a state of Nature, a fact which made his writings of interest as well as of value. Among the more important of his articles may be mentioned the various catalogues of the birds of Siam, different States of the Malay Peninsula and the larger islands, which appeared from time to time in the journals already mentioned, as well as in the Journal of the Natural History Society of Siam. His most important work, however, was the one on which he was engaged at the time of his death, which he was producing for the Government of the Malay States. It was intended that this work on the birds of that country should be divided into five parts: (1) Commoner Birds; (2) Birds of the Higher Hill Stations; (3) Sporting and Shore Birds; (4) Birds of the Low Country; and (5) Remaining Birds. Of these parts, only the first two have appeared, though we understand that part 3 was also practically finished before Mr. Robinson's death. The two volumes in print prove the great loss that ornithology has sustained in the death of Mr. Robinson.

It can scarcely be said of Mr. Robinson that he was widely popular, for he was very reserved; at the same time, the better he was known the more he was liked. In manner most unassuming, he was yet always ready to assist his brother ornithologists to the utmost of his capacity, and to these his death means the loss of a great personal friend and a clever scientific worker.

WE regret to announce the following deaths :

Dr. Etienne Bieler, deputy-director of the Imperial Geophysical Experimental Survey, at Geraldton, West Australia, on July 25, aged thirty-four years.

Dr. W. G. Duffield, Director of the Australian Commonwealth Solar Observatory at Mount Stromlo, and formerly professor of physics at University College, Reading.

Dr. T. Blackwood Murray, formerly chairman and managing director of the Albion Motor Car Co., Ltd., and a past president of the Institution of Engineers and Shipbuilders in Scotland, on June 11, aged fiftyeight years.

The Very Rev. Dr. David Paul, a past president of the Botanical Society of Edinburgh and of the British Mycological Society, on July 12, aged eighty-three years.

Dr. R. B. Riggs, Scoville professor emeritus of chemistry at Trinity College, Conn., and a member of the college faculty for thirty-three years, on May 11, aged seventy-three years.

Prof. E. M. Terry, associate professor of physics in the University of Wisconsin, known for his work on the effect of temperature on the magnetic properties of iron, cobalt, and nickel, and also on radio telephony, on May 1 , aged fifty years.

\section{News and Views.}

THE formation of a committee for the excavation of Caistor-by-Norwich, which has followed on the publication of an air photograph revealing the street plan of the Roman town, affords Dr. R. E. Mortimer Wheeler an opportunity for some pertinent comments in the June number of Antiquity on the question of the exploration of Roman Britain. In the last few years the excavation of Roman sites in Britain has been extended remarkably. It has attracted a great deal of public attention and the discovery of RomanoBritish antiquities has become 'news' in the public press. As a consequence, appeals for funds are made more widely known and meet with a more liberal response. Caistor is only one of a number of recent cases in point. At present it is true this applies in some degree to all archæological investigation; but in Romano-British archæology, as Dr. Wheeler points out, much of this effort is wasted and misdirected. $\mathrm{He}$ suggests that Romano-British research should be more systematically organised. It is expected that the complete excavation of Caistor will cost at least $£ 15,000$, and this exclusive of publication, without which research is of little value for the general advancement of knowledge.

INTERESTING as it may be expected that the results of the exploration of Caistor will prove, there are other sites, especially those in urban or developing areas, which may be regarded as more urgently in need of excavation-such sites, for example, as Caerleon, Colchester, and St. Albans, where changing conditions may in a short time preclude all digging.

No. 3119 , VoL. 124] 